\title{
The Relationship Between Leadership Style of The Head of Agency and The Employees' Performance in The Environmental Agency of Biak Numfor Regency
}

\author{
Fatmawada $S$ \\ The Institute of Social and Political Sciences of (IISIP) YAPIS Biak Papua \\ Email.fatmawadha@gmail.com
}

\begin{abstract}
This study aims to determine and explain the relationship between the leadership style of the head of the environmental agency with the employees' performance. This study uses a quantitative survey approach that is ex-post facto and principal on phenomena or events that have occurred and are still ongoing until the study is conducted, using descriptive statistical data analysis techniques, inferential descriptive analysis, and testing requirements analysis including normative data tests conducted by using the SPSS program with the Kolmogorov Smirnov One Sample test. The results of this study stated that the relationship between leadership style or leadership behavior of the head of service to the performance of employees in the Environmental Service Agency of Biak Numfor regency is not so large, only about 10 percent, which meant that the employee's performance was more determined by other variables not included in this study.
\end{abstract}

Key words: Leadership Style, Employees’ Performance.

\section{INTRODUCTION}

Leadership as a management concept in an organizational life has a strategic position and is a social phenomenon that is always needed in group life. Leadership has a strategic position, because it is the central point and dynamic of the whole process of organizational activities, so leadership has a central role in determining the dynamics of existing resources.

The presence of leaders today is very important because through leaders, all resources that are diverse can be managed and synergized into something of added value. A leader is needed to be able to unite and move other people who are led to follow their desires without feeling forced. The result of the process of leading is called leadership, in this case, leadership is expected to always lead to positive goals. Therefore, leaders must have the ability to embrace, convince, build and foster relationships between individuals so that they act according to their wishes and expectations. Heider (1986), in his book The Tao of Leadership, said "Good leadership consist of doing less and being more" where good leaders are leaders who do less and get better. Do a little and get better in the sense that the leader has careful planning, then act step by step to achieve the goals to be achieved. Surely there is a process that must be gone through in order to achieve these goals.

The leadership management of the Head of the Environment Agency of Biak Numfor Regency in presenting leadership style is not specific, but it displays a different leadership style 


\section{6| Jurnal Office: Jurnal Pemikiran Ilmiah dan Pendidikan Administrasi Perkantoran Vol. 5, No. 2, July-December 2019, Hal 85-92}

in different situations and conditions, surely the appearance of certain leadership styles is always directed towards the achievement of performance. In carrying out their duties, a leader should have three basic patterns that are used to determine the behavior of a leader, namely behavior that is oriented to the task, behavior related to cooperation / human relations, and behavior oriented to results.

In relation to leadership style, there are also various approaches, namely (1) Traits theory that emphasizes the personal attributes / characteristics of a leader, including physical and psychological aspects, (2) behavioral theory, which emphasizes that one's leadership is more determined by the behavior of the leaders, and (3) situational approach, which emphasizes that the success of leaders is more influenced by the vision and mission of the organization they lead, the nature of work, the organizational environment and the characteristics of the individuals involved in it, Indrawijaya \& Surapati (2001).

Another important thing is the concept of the effectiveness of leadership itself. A commonly used measure of leader effectiveness is the extent to which the organizational unit of the leader carries out his tasks successfully and achieves his goals. Many parameters can be used, both subjective and objective, to assess the effectiveness of the leader. The attitude of followers or subordinates towards their leaders is one indicator, for example whether followers like, respect, and admire their leaders. Do they have a commitment and obediently carry out orders or oppose and ignore them? As well as more objective behaviors can be detected through attendance rates, employee turnover per year, complaints, complaints to a higher level, requests to be moved, speed of completion of tasks, sabotage of facilities or equipment available, and so on.

Beside it is required by leaders in government organizations, professional employees are also required to support the implementation of organizational activities in these government institutions. In effort to achieve organizational goals, and to know whether an organization is growing or not, it can be determined by how the performance of employees and the performance of leaders in carrying out the tasks and responsibilities of the organization. Organizational performance as a realization of the implementation of basic tasks and functions as well as an evaluation of the existence of the organization is essential.

In an effort to improve management in the Environmental Agency of Biak Numfor Regency, a serious commitment is needed, from both leaders and employees to achieve optimal organizational goals because success or failure of an organization in carrying out its functions depends on the quality of the leaders and employees in it.

In reality, the condition of organizational management within the Agency of the Environment still needs improvements, especially improvement of employee performance that is not fully in line with expectations. For example, there are still employees who often arrive late, leave during work hours, relax, some do not engage in activities, and there are also employees who do agency work that is not based on scientific discipline resulting in gaps between employees. 
Fatmawada S; The Relationship Between Leadership Style ... 87

\section{METHOD}

This research is an ex post facto survey research and the main on phenomena or events that have occurred and are still ongoing until the research is conducted. Observations were made on the characteristics / performance variables by referring to the leadership style condition of the head of the Agency of the Environment. The location of this research is in the Environmental Agency of Biak Numfor Regency. The design of this study uses a correlational approach, with the relationship model between the variables described as follows:

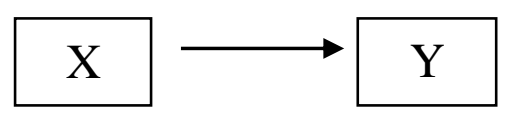

Figure 1. Variable Relationship Design

Where:

$X=$ Leadership style Head of Agency

$\mathrm{Y}=$ Employee's Performance

The instrument in this study is a questionnaire for employees of the Agency of the Environment, with the aim of obtaining an overview of the leadership style, current performance and also the relationship between the two. Furthermore, measuring employee performance with its components is done using a scale with an average and expressed by scoring according to the Likert scale, in 5 parts given numbers 5 to 1 . Then do the velocity test using the Pearson product moment, which correlates the answer score obtained at each item, which is continued to the reliability test stage using Cronbach's alpha coefficient with the formula:

$$
r_{i=\frac{k}{(k-1)}}\left\{1-\frac{\Sigma s i^{2}}{s t^{2}}\right\}
$$

Where:

$\mathrm{r}_{\mathrm{i}} \quad=$ reliability coefficient

$\mathrm{K} \quad=$ number of items

$\mathrm{S}_{\mathrm{i}} \quad=$ standard deviation of items

$\mathrm{S}_{\mathrm{t}} \quad=$ total standard deviation namely):

The calculation results are interpreted based on Guilford's criteria (in (Thoha (1991), 


$$
\begin{array}{ll}
\mathrm{R}_{\mathrm{xy}}<0,20 & =\text { Very low reliability } \\
0,20 \leq \mathrm{r}_{\mathrm{xy}}<0,40 & =\text { Low reliability } \\
0,40 \leq \mathrm{r}_{\mathrm{xy}}<0,70 & =\text { Fair reliability } \\
0,70 \leq \mathrm{r}_{\mathrm{xy}}<0,90 & =\text { High reliability } \\
0,90 \leq \mathrm{r}_{\mathrm{xy}}<1,00 & =\text { Very high reliability }
\end{array}
$$

After the instrument is filled in and returned by respondents who are the sample of the trial, then the raw data from the results of the instrument trial are made and processed with the computer program SPSS version 13.0. The population in this study was all 73 Environmental Services employees. The sampling technique in the study was carried out following the Krejcie and Morgan 1970 table guidelines in Sugiyono (2007), where the calculation of sample size was based on a $95 \%$ level of confidence, so the number of sample members would be smaller than the total population members. Thus, the number of samples in this study was 40 . Data collection techniques are using questionnaires, observations and conducting documentation studies, then performed using descriptive statistical analysis techniques in the form, average, and standard devision, and inferential statistical analysis techniques to test the hypothesis proposed the analytical tool used is a simple regression with the model:

Where:

$$
\mathrm{Y}=\mathrm{a}+\mathrm{bX} \quad \text { Sugiyono (2005) }
$$

$\mathrm{Y} \quad=$ employees' performance

a $\quad=$ regression constant

$\mathrm{b} \quad=$ regression coefficient

$\mathrm{X}=$ the leadership style of the head of agency

All data analysis starts from the validity and reliability analysis until linear regression is performed with SPSS version 13.0. The last step is to do the analysis requirements testing. Analysis requirements are intended to determine whether the data are normally distributed, have the same diversity of homogeneity and meet the linearity assumptions, Tiro \& Muhammad (2002). To find out whether the data is normally distributed or not the data normality test is performed. Data normality test is done using the SPSS program with the Kolmogorov Smirnov One Sample test. A research test result is stated to be normally distributed if the probability value is greater than 0.05 (asym. Sig> 0.05).

\section{RESULT AND DISCUSSION}

This research is an ex post facto survey research and the main on phenomena or events that have occurred and are still ongoing until the research is conducted. Observations were made on the characteristics / performance variables by referring to the leadership style condition of the head of the Agency of the Environment. The location of this research is in the 
Environmental Agency of Biak Numfor Regency. The design of this study uses a correlational approach, with the relationship model between the variables described as follows:

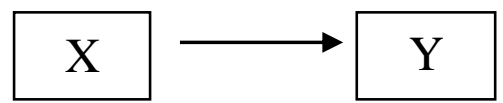

Figure 1. Variable Relationship Design

Where:

$X=$ Leadership style Head of Agency

$\mathrm{Y}=$ Employee's Performance

The instrument in this study is a questionnaire for employees of the Agency of the Environment, with the aim of obtaining an overview of the leadership style, current performance and also the relationship between the two. Furthermore, measuring employee performance with its components is done using a scale with an average and expressed by scoring according to the Likert scale, in 5 parts given numbers 5 to 1 . Then do the velocity test using the Pearson product moment, which correlates the answer score obtained at each item, which is continued to the reliability test stage using Cronbach's alpha coefficient with the formula:

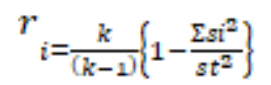

Where:

$\mathrm{r}_{\mathrm{i}} \quad=$ reliability coefficient

$\mathrm{K} \quad=$ number of items

$\mathrm{S}_{\mathrm{i}} \quad=$ standard deviation of items

$\mathrm{S}_{\mathrm{t}} \quad=$ total standard deviation

The calculation results are interpreted based on Guilford's criteria (in (Thoha (1991), namely):

$\mathrm{R}_{\mathrm{xy}}<0,20 \quad=$ Very low reliability

$0,20 \leq \mathrm{r}_{\mathrm{xy}}<0,40 \quad=$ Low reliability

$0,40 \leq \mathrm{r}_{\mathrm{xy}}<0,70 \quad=$ Fair reliability

$0,70 \leq \mathrm{r}_{\mathrm{xy}}<0,90 \quad=$ High reliability

$0,90 \leq \mathrm{r}_{\mathrm{xy}}<1,00 \quad=$ Very high reliability

After the instrument is filled in and returned by respondents who are the sample of the trial, then the raw data from the results of the instrument trial are made and processed with the computer program SPSS version 13.0. The population in this study was all 73 Environmental Services employees. The sampling technique in the study was carried out following the Krejcie and Morgan 1970 table guidelines in Sugiyono (2007), where the calculation of sample size was based on a $95 \%$ level of confidence, so the number of sample members would be smaller than the total population members. Thus, the number of samples in this study was 40 . Data collection techniques are using questionnaires, observations and conducting documentation studies, then 


\section{0| Jurnal Office: Jurnal Pemikiran Ilmiah dan Pendidikan Administrasi Perkantoran} Vol. 5, No. 2, July-December 2019, Hal 85-92

performed using descriptive statistical analysis techniques in the form, average, and standard devision, and inferential statistical analysis techniques to test the hypothesis proposed the analytical tool used is a simple regression with the model:

Where:

$$
\mathrm{Y}=\mathrm{a}+\mathrm{bX} \quad \text { Sugiyono }(2005)
$$

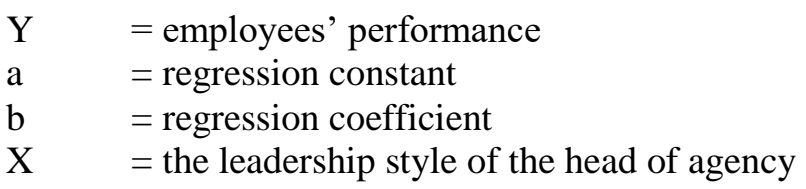

All data analysis starts from the validity and reliability analysis until linear regression is performed with SPSS version 13.0. The last step is to do the analysis requirements testing. Analysis requirements are intended to determine whether the data are normally distributed, have the same diversity of homogeneity and meet the linearity assumptions, Tiro \& Muhammad (2002). To find out whether the data is normally distributed or not the data normality test is performed. Data normality test is done using the SPSS program with the Kolmogorov Smirnov One Sample test. A research test result is stated to be normally distributed if the probability value is greater than 0.05 (asym. Sig>0.05).

\section{CONCLUSION}

Based on the results of research and data analysis about the leadership style of the head of agency on employee performance, it can be concluded that: 1) The description of the leadership style of the heads of the Agency of Environment in the Biak Numfor Regency in general is in the moderate category and is more likely to be included in the category of leadership behavior oriented toward cooperative relations / human relations (relationship oriented). 2) The description of employee performance at the Biak Numfor District Environmental Agency in general is in the category of having moderate performance, and only a small proportion of respondents have low performance.3) Based on the results of inferential statistical analysis using simple regression analysis of the results of the study, it was found that the relationship of leadership style or leadership behavior of the head of service to the performance of employees in the Agency of the Environment is not so large, only about 10 percent, which means more employees' performance is determined by other variables which is not included in this study.

\section{REFERENCES}

Heider, J. (1986). The Tao of Leadership. New York: Bantam Books.

Indrawijaya, A. I., \& Surapati, W. (2001). Kepemimpinan dalam Organisasi (Bahan Ajar Diklatpim Tingkat III). Jakarta: LAN.

Lopez, E. M. (1982). A Test of the Self-Consistency Theory of the Job Performance-Job 
Satisfaction Relationship. Academy of Management Journal, 25(2), 335-348. https://doi.org/10.5465/255995

McShine, S. L., \& Glinow, M. A. Von. (2010). Organizational Behavior. New York: McGraw-Hill.

Rivai, V. (2005). Performance Appraisal. Jakarta: PT. Raja Grafindo Persada.

Rivai, V. (2007). Kepemimpinan dan Perilaku Organisasi. Jakarta: PT. Raja Grafindo Persada.

Ropert L, M., \& Jackson, J. H. (2006). Manajemen Sumber Daya Manusia Edisi Pertama. Jakarta: Salemba Empat.

Salusu, J. (2000). Pengambilan Keputusan Stratejik. Jakarta: Gramedia Widiasarana Stratejik.

Sugiyono. (2005). Statistika untuk Penelitian. Bandung: Alfabeta.

Sugiyono. (2007). Statistik Nonparametris. Bandung: Alfabeta.

Thoha, M. (1991). Perspektif Perilaku Birokrasi. Jakarta: Rajawali Pers.

Tiro, \& Muhammad, A. (2002). Statistik Distribusi Bebas. Makasar: Andira Publisher. 
$92 \mid$ Jurnal Office: Jurnal Pemikiran Ilmiah dan Pendidikan Administrasi Perkantoran Vol. 5, No. 2, July-December 2019, Hal 85-92 